\title{
ANALISIS NILAI TAMBAH BUAH PISANG MENJADI KERIPIK PISANG PADA INDUSTRI RUMAH TANGGA DI DESA DIMEMBE KECAMATAN DIMEMBE
}

\author{
Vinny Makarawung \\ Paulus A. Pangemanan \\ Caroline B.D. Pakasi
}

\begin{abstract}
The purpose of this study is to calculate the profit and added value of the business of processing bananas into banana chips. This research is carried out for two months, from April to May 2017. The research place in one household industry of banana chips in Dimembe Village, Dimembe Sub-district, North Minahasa Regency. The method used in this research is by taking primary data and secondary data. Primary data was obtained through direct interviews using questionnaires. Secondary data is obtained through literature that supports and is associated with this research. Data analysis methods used in this study are: (1) calculate the Benefits of Banana Processing Business Being Chips, (2) calculate the Value Added Banana Chips. The results of this study indicated that the Agro-Business Processing of Banana Chips provides a benefit received is IDR 5,313,500 per month or twenty-three times of the production process. The value added enjoyed by the owner of agroindustry amounted to Rp 2.404/ $\mathrm{kg}$ from raw materials used. This added value is an advantage gained by banana chips agroindustry in 1 kilogram of raw material usage.
\end{abstract}

Keyword: analysis, value added, banana, chips, home industry, Dimembe Village, Dimembe District.

\section{ABSTRAK}

Tujuan Penelitian ini adalah menghitung keuntungan dan nilai tambah dari usaha pengolahan buah pisang menjadi keripik pisang. Penelitian ini di laksanakan selama dua bulan yaitu dari bulan April sampai Mei tahun 2017. Tempat penelitian pada satu industri rumah tangga keripik pisang di Desa Dimembe, Kecamatan Dimembe. Metode yang digunakan dalam penelitian ini adalah dengan cara mengambil data primer dan data sekunder. Data primer diperoleh melalui wawancara langsung dengan menggunakan daftar pertanyaan. Data sekunder diperoleh melalui literatur yang menunjang dan memiliki hubungan dengan penelitian ini. Metode analisis data yang digunakan dalam penelitian ini adalah : (1) menghitung Keuntungan Usaha Pengolahan Pisang Menjadi Keripik, (2) menghitung Nilai Tambah Keripik Pisang. Hasil penelitian ini menunjukkan bahwa Usaha Agroindustri Pengolahan Keripik Pisang memberikan keuntungan yang diterima adalah sebesar Rp 5.313.500 per bulan atau dua puluh tiga kali proses produksi. Nilai tambah yang dinikmati pemilik dari agroindustri sebesar Rp 2.404/kg dari bahan baku yang dimanfaatkan. Nilai tambah ini merupakan keuntungan yang didapatkan oleh agroindustri keripik pisang dalam 1 kilogram penggunaan bahan baku.

Kata Kunci: analisis, nilai tambah, pisang, keripik, industri rumah tangga, Desa Dimembe, Kecamatan Dimembe 


\section{PENDAHULUAN}

\section{Latar belakang}

Bidang pertanian saat ini merupakan salah satu bagian yang terus diupayakan untuk pengembangan agribisnis dalam rangka meningkatkan pertanian yang modern. Indonesia sebagai Negara agraris banyak menyadarkan kebutuhan hidupnya dari hasil bertani, karena itu sektor pertanian menjadi salah satu sektor yang terus diandalkan untuk menunjang laju pertumbuhan ekonomi nasional. Pembangunan agribisnis di Indonesia didukung dengan sumberdaya alam dan sumberdaya manusia yang secara kuantitas sangat mendukung namun dari segi kualitas masih kurang mendukung, karena pelaku agribisnis yang didominasi oleh petani dan berdomisili di pedesaan masih memiliki tingkat pendidikan yang relatif rendah, dengan keterampilan yang masih rendah, serta kemampuan mengakses teknologi rendah, yang menjadikannya faktor penghambat dalam pembangunan agribisnis di Indonesia. Pengembangan industri dalam pembangunan dilihat sebagai usaha untuk meningkatkan mutu sumber daya manusia (antara lain dengan meningkatkan produktivitasnya) dan kemampuannya memanfaatkan secara optimal sumber daya alam dan daya produksi lainnya. Satu sama lain hal itu harus disertai oleh usaha untuk meluaskan ruang lingkup bidang jenis kegiatan manusia. Salah satu komoditi tanaman pangan yang mampu mendukung berdirinya beberapa industri adalah buah pisang. Pisang mempunyai daya guna yang luas karena selain sebagai bahan bakuindustri pangan dan non pangan juga sebagai konsumsi rumah tangga.

Pendayagunaan pisang tidak hanya sebagai makanan untuk buah-buahan, tetapi juga sebagai produk olahan yang perdagangkan di pasar internasional, seperti campuran makanan bayi. Setiap oraang yang ingin membuat usaha atau bisnis bertujuan untuk mendapatkan keuntungan, seperti salah satu industri yang ada saat ini di Desa Dimembe Kabupaten Minahasa Utara yaitu industri pengolahan pisang sebagai bahan baku pembuatan keripik pisang, usaha ini dikelola oleh bapak Julius. Usaha buah pisang menjadi kripik pisang ini bertujuan menciptakan produk yang berkualitas tinggi agar nilai tambah yang di peroleh dari buah pisang ini semakin besar. Usaha Bapak Julius tersebut mulai berdiri pada tahun 2006 yang awalnya terdiri hanya memilik 3 (tiga) orang tenaga kerja yaitu keluarganya sendiri, dan sekarang sudah beranggotakan 2 (Dua) orang tenaga kerja. Berdasarkan survey awal diketahui bahwa pembuatan keripik pisang di lokasi penelitian seharusnya masih membutuhkan lebih banyak tenaga kerja karna setiap bulan proses produksi dilakukan dua puluh tiga kali jika sedangkan jumlah tenaga kerja yang mereka miliki hanya 2 teanga kerja, tenaga kerja yang lain adalah keluarga. Ketersediaan bahan baku pisang yang memampuni proses produksi kiranya dapat menambah pendapatan keluarga tani. Usaha agroindustri keripik pisang termasuk kedalam agroindustri makanan dengan bahan baku utama pisang merupakan usahatra disional yang banyak dilakukan masyarakat dan telah berkembang sejak lama. Usaha ini dilakukan turun temurun meskipun dari skala usaha sebagian kurang berkembang. Perkembangan usaha pembuatan keripik pisang pada Industri Rumah Tangga ditunjang dengan ketersediaan bahan baku yang ada dan cara pengolahannya menjadi keripik pisang.

\section{Perumusan Masalah}

Berdasarkan uraian diatas maka rumusan masalah pada penelitian ini yaitu berapa besar nilai tambah dari usaha pengolahan pisang menjadi keripik pisang di Desa Dimembe Kecamatan Dimembe.

\section{Tujuan Penelitiam}

Tujuan Penelitian ini adalah menganalisis nilai tambah dari usaha pengolahan buah pisang menjadi keripik pisang.

\section{Manfaat Penelitian}

1. Bagi peneliti dapat melatih cara berpikir serta menganalisis data, dan penelitian ini merupakan salah satu syarat untuk memperoleh gelar sarjana di Fakultas Pertanian Universitas Sam Ratulangi Manado.

2. Bagi pemilik usaha, diharapkan dapat menambah informasi dalam mencari besarnya keuntungan dalam usaha 
pengolahan buah pisang menjadi keripik pisang

3. Bagi peneliti lain, dapat dijadikan referensi kajian dalam bidang penelitian serupa.

\section{METODOLOGI PENELITIAN}

\section{Waktu Dan Tempat Penelitian}

Penelitian ini di laksanakan selama dua bulan yaitu dari bulan April sampai Mei tahun 2017 mulai dari persiapan sanpai penyusunan laporan penelitian. Tempat penelitian di Desa Dimembe Kecamatan Dimembe pada Industri Rumah Tangga Keripik Pisang

\section{Metode pengumpulan data}

Metode yang digunakan dalam penelitian ini adalah dengan cara mengambil data primer dan data sekunder. Data primer diperoleh melalui wawancara langsung dengan menggunakan kusioner yang berisikan pertanyaan-pertanyaan secara tertulis sedangkan Data sekunder diperoleh melalui literatur yang menunjang dan memiliki hubungan dengan penelitian ini.

\section{Konsep Pengukuran Variabel}

1. Responden yaitu pemilik dari agroindustri keripik pisang.

2. Umur responden yaitu usia dihitung sejak lahir sampai saat penelitian dilaksanakan (tahun).

3. Tingkat pendidikan adalah jenjang pendidikan yang pernah diikuti atau dilalui (tahun).

4. Jumlah tanggungan keluarga adalah semua orang yang berada di dalam rumah atau di luar rumah tetapi kehidupannya di biayai oleh pemilik (jiwa)

5. Pengalaman mengolah usaha adalah lama pemilik melakukan kegiatan usahanya (tahun).

6. Produksi adalah kuantitas hasil usaha pengolahan pisang menjadi keripik pisang yang diproduksi agroindustri, diukur dalam satuan kilogram $\mathrm{Kg}$.

7. Bahan baku merupakan pisang yang digunakan untuk menghasilkan keripik pisang yang dihitung dalam nilai tambah per bahan baku (NTbb).
8. Tenaga kerja adalah orang yang bekerja yang dihitung dalam Jumlah jam kerja (JKO).

9. Harga produk yaitu nilai jual keripik pisang yang dihitung dengan $(\mathrm{Rp} / \mathrm{Kg})$.

10. Nilai produk adalah pendapatan yang diterima penggusaha dalam penggolahan keripik pisang yang dihasilkan dihitung dalam satuan Rupiah / Nilai tambah per bahan baku (Rp / NTbb).

11. Nilai tambah adalah pengurangan biaya bahan-baku yang digunakan dengan biaya input lainnya terhadap penemuan output agroindustri yang dihasilkan termasuk biaya tenaga kerja, dihitung dalam satuan Rupiah/ Nilai tambah bahan baku (Rp/ NTbb).

12. Pendapatan industri adalah imbalan jasa yang diterima produsen dan tenaga kerja diukur dalam Rupiah /Nilai tambah bahan baku (Rp/ NTbb).

Keuntungan merupakan total penerimaan dikurangi dengan total biaya yang dihitung dalam Rupiah /Nilai tambah bahan baku (Rp/ NTbb).

\section{Metode Analisis Data}

Metode analisis data yang digunakan dalam penelitian ini adalah :

1. Menghitung Keuntungan Usaha Pengolahan Pisang Menjadi Keripik

Rumus : $\pi=\mathrm{TR}-\mathrm{TC}$

Keterangan :

$$
\begin{aligned}
\pi= & \text { Keuntungan usaha pengolahan } \\
& \text { Pisang menjadi keripik Pisang } \\
& (\mathrm{Rp} \\
\mathrm{TR}= & \text { Penerimaan usaha pengolahan } \\
& \text { Pisang menjadi keripik Pisang } \\
& (\mathrm{Rp}) \\
\mathrm{TC}= & \text { Biaya total usaha pengolahan } \\
& \text { Pisang menjadi keripik Pisang } \\
& (\mathrm{Rp})
\end{aligned}
$$

Untuk biaya total dapat dihitung dengan mengunakan rumus sebagai berikut :

Rumus : $\mathrm{TC}=\mathrm{TFC}+\mathrm{TVC}$

Keterangan :

$\mathrm{TC}=$ Biaya total usaha pengolahan pisang menjadi keripik pisang (Rp)

TFC = Biaya tetap usaha pengolahan pisang menjadi keripik pisang (Rp) 
TVC = Biaya variabel usaha pengolahan pisang menjadi keripik pisang $(\mathrm{Rp})$

Untuk menghitung penerimaan dapat dihitung dengan menggunakan rumus sebagai berikut :

Rumus : $\mathrm{TR}=\mathrm{Q} \times \mathrm{P}$

Keterangan :

$$
\begin{aligned}
\mathrm{TR}= & \begin{array}{l}
\text { Penerimaan total usaha } \\
\text { pengolahan pisang menjadi } \\
\text { keripik pisang }(\mathrm{Rp})
\end{array} \\
\mathrm{Q}= & \begin{array}{l}
\text { Jumlah produk keripik pisang } \\
\text { (Bungkus) }
\end{array} \\
\mathrm{P}= & \begin{array}{l}
\text { Harga produk keripik pisang } \\
(\mathrm{Rp})
\end{array}
\end{aligned}
$$

2. Menghitung Nilai Tambah Keripik Pisang

a. Nilai Tambah Bruto

$$
\begin{aligned}
\mathrm{NTb} & =\mathrm{Na}-\mathrm{Ba} \\
& =\mathrm{Na}-(\mathrm{Bb}+\mathrm{Bp}) \\
\text { Keterangan : } & \\
\mathrm{NTb}= & \text { Nilai tambah bruto (Rp) } \\
\mathrm{Na}= & \text { Nilai produk akhir keripik } \\
& \text { pisang (Rp) } \\
\mathrm{Ba}= & \text { Biaya antara(Rp) } \\
\mathrm{Bb}= & \text { Biaya bahan baku keripik } \\
& \text { pisang (Rp) } \\
\mathrm{Bp}= & \text { Biaya bahan penolong } \\
& (\mathrm{Rp})
\end{aligned}
$$

b. Nilai Tambah Netto (NTn)

$$
\begin{aligned}
& \mathrm{NTn}=\mathrm{NTb}-\mathrm{NP} \\
& \mathrm{NP}=\frac{\text { Nilai Awal }}{\text { Umur Ekonomis }}
\end{aligned}
$$

Keterangan :

$\mathrm{NTn}=$ Nilai tambah netto $(\mathrm{Rp})$

$\mathrm{NTb}=$ Nilai tambah bruto (Rp)

$\mathrm{NP}=$ Nilai penyusutan $(\mathrm{Rp})$

c. Nilai Tambah per Bahan Baku

$\mathrm{NTbb}=\mathrm{NTb}: \sum \mathrm{bb}$

Keterangan :

$\mathrm{NTbb}=$ Nilai tambah per bahan $(\mathrm{Rp} / \mathrm{Kg})$

$\mathrm{NTb}=$ Nilai tambah bruto (Rp)

$\sum \mathrm{bb}=$ Jumlah bahan baku yang digunakan $(\mathrm{Kg})$

\section{PEMBAHASAN}

\section{Gambaran Umum Usaha Keripik Pisang}

Usaha Kripik Pisang adalah usaha pengolahan pisang menjadi kripik pisang yang bertempat di Desa dimembe dan dikelolah oleh Bapak Junius yang mulai berdiri pada tahun 2006 sampai sekarang dan awalnya dia hanya bersama istri setelah memiliki modal yang cukup kemudian dia memiliki 2 (dua) orang tenaga kerja sewa.

\section{Identitas Pemilik}

Identitas pemilik usaha kripik pisang: umur, lama pendidikan, pengalaman berusaha, dan tanggungan keluarga. Untuk lebih jelasnya dapat dilihat pada Tabel 1.

\begin{tabular}{llc}
\multicolumn{3}{c}{ Tabel 1. Identitas Pemilik Usaha Kripik Pisang di Desa } \\
Dimembe
\end{tabular}

\section{Umur Pemilik}

Hasil penelitian menunjukan umur pemilik usaha kripik pisang adalah 44 tahun. Kondisi tersebut menunjukkan bahwa pemilik termasuk kategori penduduk usia kerja dalam melakukan usaha pengolahan pisang menjadi kripik pisang dan tergolong memiliki usia lebih dinamis dalam bertindak, mempunyai kemampuan fisik yang kuat dan keberanian dalam mengambil suatu keputusan serta berani mengambil resiko terhadap kegagalan dalam melakukan usaha.

\section{Tingkat Pendidikan}

Tingkat pendidikan yang relatif tinggi dan umur yang muda menyebabkan seseorang lebih cenderung dinamis yang tercermin melalui cara kerja, pola pikir dan mudah tidaknya dalam menerima informasi. Semakin tinggi pendidikan formal pemilik, maka pengetahuan dan wawasannya semakin luas serta cara berpikirnya akan semakin rasional. Dengan demikian akan mempercepat proses adopsi inovasi dan informasi dalam upaya mengembangkan usaha yang 
dikelolanya. Hasil penelitian menunjukkan bahwa pemilik memiliki tingkat pendidikan Sekolah Menengah Atas (SMA). Pendidikan formal diharapkan dapat mendukung dalam menyerap berbagai informasi tentang kegiatan yang terkait dengan nilai tambah maupun bidang usaha.

\section{Jumlah Tanggungan Keluarga}

Hasil penelitian menunjukan bahwa jumlah anggota keluarga pemilik adalah 4 orang, keadaan tersebut menggambarkan bahwa pemilik termasuk keluarga sedang. Dengan jumlah anggota keluarga yang demikian, maka diharapkan sebagian anggota keluarga sudah berada pada usia produktif sehingga dapat menjadi sumber tenaga kerja untuk membantu pengolah dalam mengelola usahanya.

\section{Pengalaman Berusaha Pengolah Buah Pisang Menjadi Keripik Pisang}

Hasil penelitian menunjukan bahwa pengalaman pemilik dalam usahanya adalah 10 tahun (cukup berpengalaman), hal ini menunjukkan bahwa pemilik pengolah sudah memiliki pengetahuan dan pengalaman yang cukup baik terkait nilai tambah dan bidang usaha.

\section{Karakteristik Usaha}

\section{Penggunaan Peralatan}

Perencanaan pengadaan peralatan dari bahan baku yang efektif dan efisien dapat menjadikan kegiatan produksi berjalan lancar dan dapat meningkatkan hasil dan keuntungan bagi agroindustri pengolahan keripik pisang Bapak Julius. Rincian penggunaan peralatan pada agroindustri pengolahan keripik pisang Bapak Julius tahun 2017 dapat dilihat pada Tabel 2.

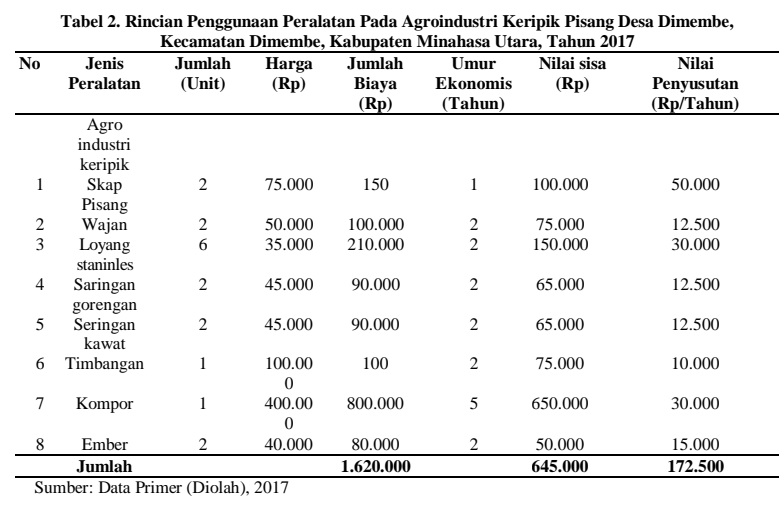

Tabel 2 menunjukan bahwa total biaya peralatan yang dikeluarkan oleh agroindustri pengolahan keripik pisang di Desa Dimembe, Kecamatan Tanah Dimembe, Kabupaten Minahasa Utara adalah Rp. 1.620.000. Biaya peralatan yang terbesar untuk pembelian kompor Rp. 800.000. dan biaya terendah yang dikeluarkan untuk pembelian ember Rp. 40.000. secara keseluruhan nilai penyusutan peralatan sebesar Rp. 172.500 per tahunnya.

\section{Penyediaan Bahan Baku}

Bahan baku merupakan bahan mentah yang diolah dan dapat dimanfaatkan sebagai sarana produksi dalam suatu agroindustri. Ketersediaan bahan baku secara cukup dan berkelanjutan akan menjamin suatu perusahaan untuk bisa berproduksi dalam waktu yang relatif lama. Dalam melakukan pengolahan keripik pisang, bahan baku utama yang digunakan adalah pisang, sedangkan bahan baku penolong lain yang digunakan adalah minyak goreng, garam, gula, bawang putih. Bahan baku dan bahan penolong dapat diperoleh dengan mudah karena ketersediaan maupun harga yang terjangkau sehinggga tidak menjadi suatu hambatan bagi agroindustri keripik pisang.

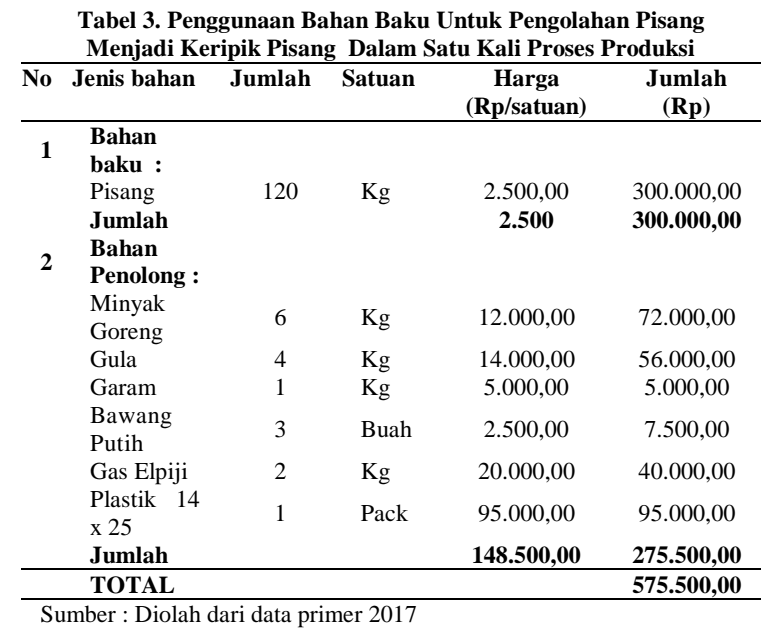

Tabel 3 menunjukkan bahwa bahan baku yang terbesar digunakan dalam satu kali proses produksi keripik pisang adalah untuk pembelian bahan baku utama yaitu sebesar Rp 300.000. Sedangkan biaya terendah yang dikeluarkan untuk pembelian garam sebesar $\mathrm{Rp}$ 5.000. jumlah bahan baku penolong yang dikeluarkan sebesar Rp 275.500. Dengan total keseluruhan biaya digunakan untuk pengolahan keripik pisang adalah sebesar Rp 575.500. 


\section{Proses Produksi Keripik Pisang}

Uraian kegiatan yang dilakukan dalam proses produksi pengolahan keripik pisang adalah sebagai berikut :

\section{Pengadaan Bahan Baku}

Bahan baku yang digunakan dalam pembuatan keripik pisang ini pada dasarnya adalah sama pada tiap-tiap agroindustri lainnya, yaitu pisang, gula, garam dan bawang merah sebagai bahan baku, pemakaiannya sebagai berikut : Misalkan dalam setiap satu kali proses produsi untuk 120 $\mathrm{kg}$ pisang, bahan tambahan (gula, garam, dan bawang merah) yang dibutuhkan adalah 3 buah bawang merah, $1 \mathrm{~kg}$ garam, dan $4 \mathrm{~kg}$ gula dan jumlah bahan tambahan atau penolong ini bisa disesuaikan menurut selera serta dari bahan baku yang digunakan.

2. Proses Produksi

Dalam malakukan proses produksi pengolahan keripik pisang pada dasarnya memiliki tahapan yang sama, adapun tahapan tersebut adalah sebagai berikut :

1. Pengupasan. Pisang yang telah dipilih dikupas kemudian, kemudian menggunakan skap diiris tipis-tipis tebal kira-kira 2-3 $\mathrm{mm}$ secara memanjang kemudian masukan pisang yang telah dikupas kedalam wadah lalu tambahkan gula, garam dan bawang merah yang telah dibersihkan, aduk rata.

2. Penggorengan. Pisang yang sudah diris dimasukan kedalam wajan yang telah diisi dengan minyak panas. Penggorengan dilakukan didalam minyak bersuhu $170 \mathrm{c}$. minyak harus cukup banyak sehinnga bahan sehingga semua bahan bisa tercelup kedalam minyak. Selama penggorengan, dilakukan pengadukan secara pelan-pelan. Penggorengan dilakukan sampai kripik cukup kering dan garing.

3. Pengemasan. Sebelum dikemas keripik pisang didinginkan terlebih dahulu lalu dimasukkan ke plastik kemasan.

\section{Produksi dan Nilai Produksi Keripik}

Produksi adalah segala kegiatan yang ditujukan untuk menciptakan dan menambahkan keragaman makanan atau barang dan jasa. Produksi merupakan pendapatan kotor dalam bentuk fisik dari suatu proses produksi. Sedangkan nilai produksi merupakan pendapatan kotor yang diperoleh dari hasil perkalian jumlah dan harga jual yang berlaku di pasaran. Produksi, harga jual dan nilai produksi dapat dilihat pada Tabel 4.
Tabel 4. Rincian Produksi, Harga Jual dan Nilai Produksi Keripik Pisang Agroindustri Pengolahan Keripik Pisang di Desa Dimembe \begin{tabular}{ccccc}
\multirow{2}{*}{ Tahun } & \multicolumn{4}{c}{ Kecamatan Dimembe } \\
\cline { 2 - 5 } & Produksi & Produksi & Harga Jual & Pendapatan \\
\hline 2016 & 828 & 9.936 & $(\mathrm{Rp} / \mathrm{Kg})$ & $(\mathrm{Rp} / \mathrm{bulan})$ \\
\hline
\end{tabular} \begin{tabular}{ccc}
2016 & 828 & 9.936 \\
\hline Sumber : Diolah dari data primer 2017
\end{tabular}

Tabel 4 menunjukkan bahwa selama melakukan proses produksi, selama pada tahun 2017 produksi keripik pisang stabil karena bisa memproduksi kripik pisang setiap harinya (kecuali hari minggu) hal itu dilihat dari ketersediaan bahan baku yang memampuni sehingga membuat agroindustri mampu berproduksi setiap harinya, agroindustri ini berproduksi $9.936 \mathrm{~kg} /$ tahun dengan harga jual Rp 24.000/kg.

\section{Biaya Produksi dan Pendapatan}

Tujuan dari analisis biaya usaha pengolahan keripik pisang adalah untuk menggolongkan biaya menurut fungsi pokok dalam usaha dan menurut perilakunya dalam perubahan volume kegiatan usaha.

\begin{tabular}{|c|c|c|c|c|c|c|}
\hline No & $\begin{array}{c}\text { Jenis } \\
\text { Pengeluaran }\end{array}$ & Volume & Satuan & $\begin{array}{c}\text { Harga } \\
\text { (satuan) }\end{array}$ & Jumlah & $\%$ \\
\hline \multirow[t]{2}{*}{1} & Bahan baku & & & & & \\
\hline & $\begin{array}{l}\text { Pisang } \\
\text { Jumlah }\end{array}$ & 2760 & $\mathrm{Kg}$ & 2.500 & $\begin{array}{l}6.900 .000 \\
6.900 .000\end{array}$ & 46,5 \\
\hline \multirow[t]{8}{*}{2} & $\begin{array}{l}\text { Bahan } \\
\text { Penolong }\end{array}$ & & & & & \\
\hline & Minyak goreng & 138 & $\mathrm{Kg}$ & 12.000 & 1.656 .000 & 11,2 \\
\hline & Gula & 92 & $\mathrm{Kg}$ & 14.000 & 1.288 .000 & 8,7 \\
\hline & Garam & 23 & $\mathrm{Kg}$ & 5.000 & 115.000 & 0,8 \\
\hline & Bawang Putih & 69 & Buah & 2.500 & 172.500 & 1,2 \\
\hline & Gas Elpiji & 46 & $\mathrm{Kg}$ & 20.000 & 920.000 & 6,2 \\
\hline & Plastik 14 × 25 & 23 & Pack & 95.000 & 2.185 .000 & 14,7 \\
\hline & Jumlah & & & & 6.336.500 & \\
\hline \multirow[t]{3}{*}{3} & $\begin{array}{l}\text { Biaya Tenaga } \\
\text { Kerja }\end{array}$ & & & & & \\
\hline & $\begin{array}{ll}\text { Tenaga } & \text { Kerja } \\
\text { Harian } & \end{array}$ & 46 & HK & 25.000 & 1.150 .000 & 7,7 \\
\hline & Jumlah & & & & 1.150 .000 & \\
\hline \multirow[t]{2}{*}{4} & $\begin{array}{l}\text { Biaya } \\
\text { Transportasi }\end{array}$ & & & & & \\
\hline & $\begin{array}{l}\text { Transportasi } \\
\text { Jumlah }\end{array}$ & 69 & Liter & 6.450 & $\begin{array}{l}444.050 \\
\mathbf{4 4 4 . 0 5 0}\end{array}$ & 3 \\
\hline & mlah Biaya & & & & $\begin{array}{l}14.830 .55 \\
0\end{array}$ & 100 \\
\hline
\end{tabular}

Tabel 5 menunjukan bahwa biaya pembelian bahan baku pisang merupakan komponen biaya terbesar dalam usaha pengolahan keripik pisang. Hal ini terlihat dari persentase di dalam tabel diatas sebesar 46,5\% dari keseluruhan biaya yang dikeluarkan untuk proses produksi keripik pisang. Tingkat upah tenaga kerja ditentukan pada tingkat upah yang berlaku, lama kerja dan jumlah hari kerja. Secara keseluran jumlah biaya yang harus dikeluarkan oleh agroindustri pengolahan keripik ubi kayu 
adalah sebesar Rp. 14.830.550. Agroindustri ini termasuk usaha yang masuk katagori padat modal, itu dibuktikan dengan biaya yang dikeluarkan mencapai $46,5 \%$ untuk pengadaan bahan baku pisang dalam dua puluh tiga kali proses produksi. Biaya tetap usaha pengolahan keripik pisang terdapat pada biaya produksi yaitu biaya penyusutan pada alat-alat yang digunakan dalam proses produksi serta penyusutan bangunan yang dihitung berdasarkan umur ekonomis.

Tabel 6. Biaya Produksi Pendapatan dan Keuntungan

\begin{tabular}{lll}
\multicolumn{3}{c}{ Agroindustri Keripik Pisang } \\
\hline No. & \multicolumn{1}{c}{ Keterangan } & Harga (Rp) \\
\hline 1. & $\begin{array}{l}\text { Pendapatan agroindustri } \\
\text { Total produksi/ } 828 \mathrm{~kg} \times 24.000\end{array}$ & 19.872 .000 \\
& (TR) & \\
\hline 2. & Biaya Agroindustri & 6.900 .000 \\
& a. Biaya bahan baku & 172.500 \\
& b. Biaya penyusutan & 6.336 .000 \\
& c. Biaya bahan penolong & 1.150 .000 \\
& d. Biaya tenaga kerja & 444.050 \\
\hline 3. & Keuntungan (TR - TC) & $\mathbf{4 . 8 6 9 . 4 5 0}$ \\
\hline Sumberaya Transportasi &
\end{tabular}

Sumber : Diolah dari data primer 2017

Keseluruhan jumlah biaya yang dipakai dalam 1 bulan dua puluh tiga kali proses produksi adalah sebesar Rp. 15.002.550 dengan menggunakan bahan baku utama pisang sebanyak $2760 \mathrm{~kg}$ dapat menghasilkan $828 \mathrm{~kg}$ keripik pisang. Usaha pengolahan pisang pada industri rumah tangga keripik pisang memperoleh penerimaan kotor sebesar Rp. 19.872.000, setelah dikurangi biaya-biaya maka keuntungan bersih yang didapat adalah Rp. 4.869.450.

\section{Analisis Nilai Tambah Bahan Baku Keripik Pisang}

Analisis nilai tambah usaha pengolahan pisang menjadi keripik pisang dilakukan untuk mengetahui besarnya nilai yang ditambahkan pada bahan baku yang digunakan dalam memproduksi keripik pisang, perhitungan analisis nilai tambah pisang dapat dilihat pada Tabel 7.

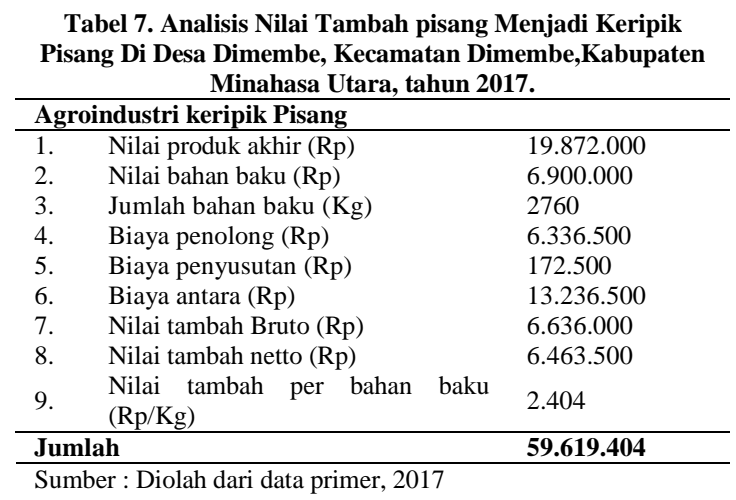

Tabel 7 menjelaskan analisis nilai tambah yang meliputi nilai tambah bruto, nilai tambah netto, nilai tambah per bahan baku. Dalam hasil penelitian ini nilai produk akhir atau penerimaan kotor sebesar Rp. 19.872.000. Bahan baku pisang yang digunakan sebanyak $2760 \mathrm{~kg} /$ bulan dalam 23 kali proses produksi dengan nilai bahan baku yang dikeluarkan sebesar Rp. $6.900 .000 \quad$ (23 kali proses produksi). Biaya penolong yang di keluarkan dalam 23 kali proses produksi setiap bulannya yaitu sebesar Rp. 6.336 .500 yang meliputi pembelian bahan penolong yaitu minyak goreng, gula, garam, bawang putih, gas elpiji, dan plastic $12 \times 25$. Sedangkan Biaya penyusutan yang dikeluarkan sebesar $\mathrm{Rp}$. 172.500 .

Nilai tambah bruto merupakan dasar dari perhitungan nilai tambah netto dan nilai tambah per bahan baku. Analisis nilai tambah pisang dengan produk akhir yang diterima oleh agroindustri keripik pisang adalah nilai yang diberikan atau dijual dari agroindustri kepada konsumen. Besarnya biaya antara yang dikeluarkan Rp. 13.263.500 yang diperoleh dari penjumlahan antara biaya bahan baku, dan biaya bahan penolong, yang masing-masing sebesar Rp. 6.900.000 dan Rp. 6.336.500 semakin besar biaya antara maka nilai tambah bruto yang diciptakan akan semakin kecil. Semakin besar nilai tambah maka semakin besar keuntungan yang diperoleh dan juga sebaliknya. secara sistematis perhitungan nilai tambah bruto :

Nilai tambah Bruto (NTb)

$$
\begin{aligned}
\mathrm{NTb} & =\mathrm{Na}-\mathrm{Ba} \\
& =\mathrm{Na}-(\mathrm{Bb}+\mathrm{BP}) \\
\mathrm{Ba} & =6.900 .000+6.336 .500 \\
\mathrm{NTB} & =13.236 .000 \\
& =6.872 .000-13.236 .000 \\
& =6.635 .000
\end{aligned}
$$

Nilai tambah netto pada petani pisang sebesar $\mathrm{Rp}$ 6.463.500 diperoleh dari selisih antara nilai bruto sebesar $\mathrm{Rp} 6.636 .000$ dan biaya penyusutan sebesar $\mathrm{Rp} 172.500$. secara sistematis perhitungan nilai tambah netto :

Nilai Tambah Netto (NTn)

$$
\begin{aligned}
\text { NTn } & =\mathrm{NTb}-\mathrm{NP} \\
& =6.636 .000-172.500 \\
& =6.463 .500
\end{aligned}
$$

Nilai tambah per bahan baku merupakan produktivitas bahan baku yang dimanfaatkan untuk mengahasilkan produk keripik pisang. 
Nilai tambah per bahan baku keripik pisang pada agroindustri di Desa Dimembe, Kecamatan Dimembe, Kabupaten Minahasa Utara yaitu sebesar Rp 2.404/Kg, artinya untuk setiap satu kilogram bahan baku pisang yang digunakan dalam produksi dapat memberikan nilai tambah bahan baku sebesar Rp 2.404. Besarnya nilai tambah tersebut diperoleh dari nilai tambah bruto sebesar Rp 6.636.000 dibagi dengan jumlah bahan baku yang digunakan yaitu sebanyak $2760 \mathrm{~kg}$. secara sitematis perhitungan nilai tambah perbahan baku :

Nilai Tambah Perbahan Baku

$$
\begin{aligned}
\mathrm{NTbb} & =\mathrm{NTb}: \sum \mathrm{bb} \\
& =6.636 .000: 2760 \\
& =2404
\end{aligned}
$$

\section{KESIMPULAN DAN SARAN}

\section{Kesimpulan}

Berdasarkan uraian hasil dan pembahasan, maka dapat disimpulkan dalam penelitian ini yaitu Agroindustri Pengolahan Keripik Pisang memberikan keuntungan yang diterima adalah sebesar Rp 5.313.500 per dua puluh tiga proses produksi selama satu bulan. Nilai tambah yang dinikmati pemilik dari agroindustri sebesar Rp 2.404/kg bahan baku yang dimanfaatkan. Nilai tambah ini merupakan keuntungan yang didapatkan oleh agroindustri keripik pisang dalam 1 kilogram penggunaan bahan baku. Dengan adanya agroindustri pengolahan pisang menjadi keripik pisang memberikan keuntungan tersendiri bagi petani pisang dimana petani dapat menjual pisang secara borongan kepada industri keripik pisang.

\section{Saran}

Berdasarkan kesimpulan penelitian, maka saran yang dapat diajukan adalah Usaha pengolahan Pisang menjadi keripik pisang yang dilakukan pengolah perlu terus dikembangkan dengan meningkatkna jumlah bahan baku yang diolah, menambah jumlah tenaga kerja, karena terbukti usaha tersebut mampu menberikan keuntungan dan nilai tambah.

\section{DAFTAR PUSTAKA}

Asmiati, 2012. Analisis Nilai Tambah Pengolahan Ubikayu di Kecamatan Batauga Kabupaten Boton. Universitas Haluoleo. Kendari.

Badan Pusat Statistik Sulawesi Utara. 2007. Direktori Industri Pengolahan. Manado.

Baroh, I. 2007. Analisis Nilai Tambah dan Distribusi Keripik Nangka Studi Kasus pada Agroindustri Keripik Nangka di Lumajang. LP UMM. Malang.

Elinda,S, dan Hamidi, W. 2008. Analisis Pendapatan Agroindustri Rengginang Ubikayu.(Online).Volume17.Nomor2h ttp://download.portalgaruda.org/article .php?article $=31398 \&$ val $=2268$. $($ diakse s Juni 2017).

Hafsah, MJ. 2003.Bisnis Ubi kayu Indonesia. Jakarta : Pustaka Sinar Harapan

Hery. 2009. Teori Akuntansi. Kencana Prenada Medi aGroup. Jakarta.

Ilchaidir.2011. Analisis Nilai Tambah Produk Jambu Metedi Kota Kendari Provinsi Sulawesi Tenggara (Studi Kasus UD.Mubaraq Lombe Kota Kendari. Universitas Halu Oleo. Kendari.

Kartikawati, Muliasari. 2007. Kajian Proses Pengolahan Dan Analisa Ekonomi Keripik Pisang di UKM Sari Madu Tani. Universitas Padjadjara. Bandung.

Kalakota, Ravi dan Marcia Robinson, 2001. EBusiness 2.0 Roadmap For Success. Addison - Wesley. USA.

Makki, M. F. et al. 2001. Nilai Tambah Agroindustri pada Sistem Agribisnis Kedelai di Kalimantan Selatan. Dalam jurnal Agro Ekonomika. Vol. VI. No. 1. Juli 2001.

Taringan, Robinson, 2007. Ekonomi Regional, Teori dan Aplikasi. PT Bumi Aksara, Cetakan keempat, Jakarta.

Valentina, O. 2009. Analisis Nilai Tambah Ubi Kayu Sebagai Bahan Baku Keripik Singkong di Kabupaten Karanganyar. Universitas Sebelas Maret : Surakarta. 